\title{
WATER MANAGEMENT STRATEGIES UNDER DEFICIT IRRIGATION
}

\author{
Antonina Capra, Simona Consoli, Baldassare Scicolone
}

\section{Introduction}

Water is becoming scarce, both in quantity and quality, not only in traditionally prone arid and semiarid zones, but also in regions where rainfall is abundant. Agriculture represents the major user worldwide, and a general perception that agricultural use is often wasteful and has less value than other uses is widespread [39]. Furthermore, energy analysis of agricultural operations has shown that irrigation consumes a significant amount of energy as compared to other operations [49]. For these reasons, there is an urgent need to use water resources efficiently by enhancing crop water productivity.

Deficit irrigation $(D I)$, the application of irrigation rates below the full crop evapotranspiration $(E T)$, is potentially able to improve efficiency and maximize profits through a reduction in capital and operating costs. Although the DI concept dates back to the 1970 s $[11,13,25]$, and the theoretical basis and analytical frameworks for DI are well established [12, 13], this technique is not usually adopted as a practical alternative to full irrigation by either academics or practitioners. An obstacle is related to the need for precision irrigation required by $D I$ strategies, the use of highly efficient irrigation systems, and prediction of the cost function and crop price. Considering that this knowledge spans a wide range of disciplines, from eco-physiology and plant sciences to hydrology, engineering and economics, the approach to DI may often be hard. Another reason for the slow progress of DI is the risk associated with the uncertainty of the knowledge required [12]. Uncertainty is associated with optimal water use estimation, e.g. lack of accuracy in crop ET data; no a priori information about the production function or data available only for specific

\section{Paper received 05.03.2008; accepted 28.07.2008}

Prof. Antonina CAPRA, Associate Professor, STAFA Dept., Mediterranean University of Reggio Calabria, acapra@unirc.it Dr. SimONA Consoli, Researcher, IA Dept., University of Catania, simona.consoli@unict.it Dr. Baldassare Scicolone, Consultant Agronomist, Catania, bscicol@tin.it

The authors have made an equal contribution to the work. locations or seasons or very few years. Generally, a priori crop production function data is missing due to a number of unpredictable factors such as climate change, irrigation system failure, germination rates, or disease impact.

Furthermore, the amount of irrigation water for certain crop yields depends on the irrigation scheduling strategy. Published results of experimental research into crop response to water and progress in hydrological and crop growth/yield models could contribute towards the application of DI strategies. The uncertainty discussed above implies risk. English et al. [12] suggest that simulation models could be used not only to predict optimal levels of irrigation water but also to quantify prediction uncertainties.

Finally, in the literature there is a certain amount of confusion regarding the $D I$ concept and, as described in the following section, the term DI is used indifferently for different water management strategies.

The aim of this paper is to synthesize the basic concepts and the main techniques of $D I$ and to present the main research results. The paper includes, as an example, a short description of a recent experimental research project conducted by the authors, which integrates agronomic, engineering and economic aspects of $D I$ at farm level.

\section{Concepts and techniques of deficit irrigation}

The concept of deficit irrigation was introduced as an economic concept in the 1970s [25] and the first research appeared in the early ' 80 s $[11,20]$. English [12, $13,14]$ defines $D I$ as the deliberate and systematic under-irrigation of crops to achieve, under some circumstances, the maximum attainable income for an irrigated field. Lecler [28] made the definition of English more explicit: $D I$ is an optimization strategy whereby net returns are maximized by reducing the amount of irrigation water applied to a crop to a level that results in some yield reduction caused by water stress. Other authors deal with $D I$ as an irrigation strategy to maximize yield with a minimum rate of water application and only deal with the physiological and agronomical 
aspects of DI (crop response to different irrigation regimes) without any economic evaluation.

In the latter case, it is more appropriate to use the term Regulated Deficit Irrigation (RDI or CDI - Controlled Deficit Irrigation as introduced by [13]) for irrigation strategies based only on a reduction of irrigation amounts during certain plant cycle phases [7]. Research into RDI could also concern the crop coefficient $\left(\mathrm{K}_{\mathrm{c}}\right)$ in different phenological phases. This kind of study is a fundamental step (but not the only one) to implement $D I$ strategies. In fact, the analyst must rely on a crop production function that links water use to crop yield in order to plan, design or manage irrigation systems under $D I$. Another strategy, initially used for grapevines [9], is Partial Root Drying (PRD), an irrigation technique by which half of the root zone is kept under dry soil, alternating irrigation from one half to the other.

A review of about 100 papers recently published in major international journals (most of which are cited in the References) has shown that only a few [12, 23, 24, 32, 38, 43, 44] use the English definition in its complete sense (e.g. by analysing the economics of $D I$ ).

\subsection{Economics of deficit irrigation}

Recognition of the following key factors is extremely important to understand the potential benefits of $D I[12,13,28]$ : the efficiency of irrigation water decreases as the application depth increases; irrigation water application is expensive; the water saved by reducing irrigation depth may allow to extend the amount of irrigated land (opportunity cost of water); the determination of an optimal irrigation strategy depends on whether a land or water shortage is the limiting production factor.

$D I$ increases water use efficiency for several reasons $[22,44]$. Firstly, an increase in application efficiency occurs when the amount of water applied is lower than full $E T$, because (most or all of) the applied water remains in the root zone (e.g. water losses due to run-off and deep percolation are reduced). The consumption efficiency (i.e. the ratio between the amount of evapotranspired water and the amount of water in the root zone) may increase because crops are forced to extract higher water levels from the soil. Furthermore, the yield efficiency (i.e. the proportion of biomass in the harvested product) may be enhanced due to an excessive vegetative growth of some crop species (cotton and grapevines, for example) under full irrigation.

The relationship between irrigation water $(w)$ and crop yield $(y)$ may be generally expressed by a quadratic form equation (Figure 1),

$$
y(w)=a_{1}+b_{1} w+c_{1} w^{2}
$$

The estimated revenue from irrigation $(R)$, obtained by multiplying the production function by a constant (crop price, $P_{c}$ ), has the same form as the production function (curved line in Figure 2),

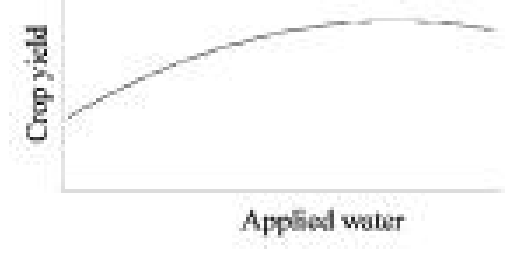

Fig. 1 - General form of crop production function.

$$
R(w)-P_{c} \cdot y(w)
$$

The straight line in Figure 2 represents a possible function relating total production costs $(c)$ to applied water:

$$
c(w)=a_{2}+b_{2} w
$$

When different water depths modify both yield and crop cycle length, the cost function may be nonlinear $[4,6]$.

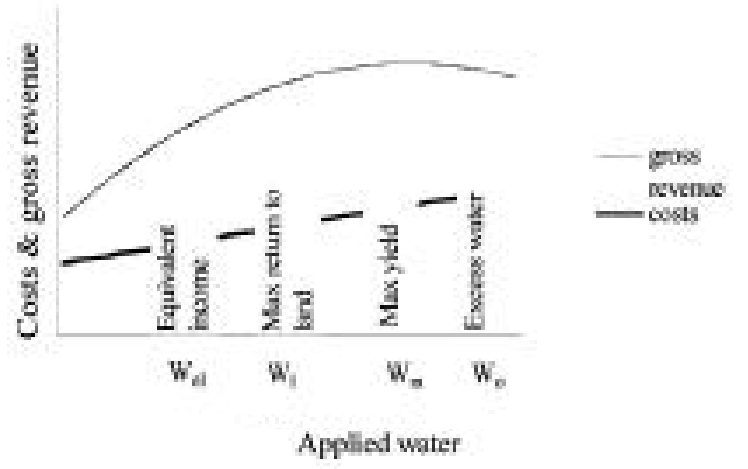

Fig. 2 - Cost and gross revenue functions versus applied water.

The vertical axis intercept, $a_{2}$, is associated with fixed costs: capital costs, taxes, insurance, fixed costs of tillage, planting, chemical use and harvesting. The slope represents the marginal variable costs of production that include variable costs of irrigation (water costs, pumping costs, labour and maintenance) and other costs based on yield variation with water use (costs associated with fertilizers, when farmers adjust them for the expected crop production, harvest costs, etc...). English et al. [12] recommend to analyse both the direct costs of irrigation and the other production costs. Incomplete cost analysis may lead to underestimation of the optimal deficit magnitude and the related potential gain in net income. The upper limit represents the maximum water delivering capacity of the system. When saved water, obtained by reducing water depths, can be used to irrigate additional land, farmers can increase their income. This potential increase represents the opportunity cost of the water. For example, $50 \mathrm{~mm}$ of water could be applied to 1 ha, or $25 \mathrm{~mm}$ could be applied to 2 ha, thus producing an increase in total profit. 
If land is limited, the main concern is what irrigation depth produces the maximum difference between costs and yield return. Since the optimal level of irrigation (when land or water are limited) requires less water than the level maximizing yield, the system may have a lower capacity and lower capital costs. As shown in Figure 3, a lower cost function corresponds to a higher difference between costs and yield return (net return). Obviously, a lower system capacity represents a limitation in certain situations, for example when several crops are irrigated in rotation and deficit irrigation strategies can only be applied to some of them.

The optimum water depth level will be the one that allows maximum profit per water unit or per land unit, depending on whether water or land is the limiting factor.

English [13] identified the following five optimum levels of applied water, which provide maximum food production or profit with a limited availability of resources (e.g., land or water):

a) level at which crop yield per unit of land is maximized, $W_{m}$

$b)$ level at which net income per unit of land is maximized, $W_{l}$

c) level at which net income per unit of water is maximized, $W_{w}$

d) level at which net income equals that at full irrigation when land is limited, $W_{e l}$

e) level at which net income equals that at full irrigation when water is limited, $W$

At the $W_{m}$ level (see figure 2 ), the application of additional water does not increase yield, thus the marginal water use efficiency is zero. Marginal water use efficiency increases as water depth decreases.

Profit per unit of land reaches its maximum when the level of applied water is $W_{l}$; at this point the cost line slope equals that of the revenue line and the net income per unit of water (difference between revenue and cost) is maximum. Within the range between $W_{l}$ and $W_{m}$ growers may benefit from cost reductions. If additional land can be irrigated, the optimal water use strategy to maximize profit could be to irrigate below $W_{l}$, indicated as the $W_{e l}$ level At optimal levels $W_{e l}$. (land-limiting case) and $W_{e w}$ (water-limiting case) the vertical difference between the revenue and cost lines equals that at level $W_{m}$. Within the range between $W_{e l}$,

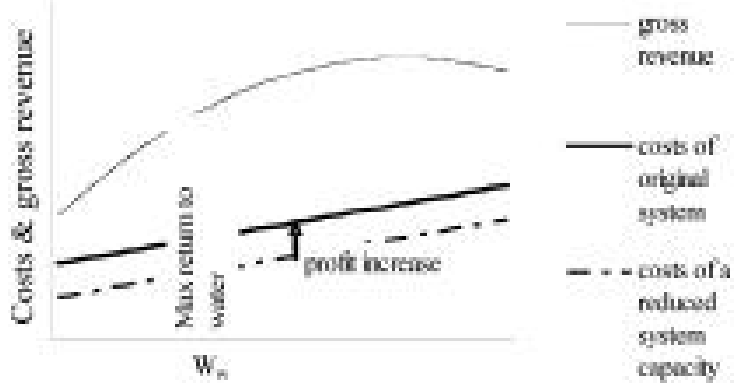

Fig. 3 - Effects of reduced system capacity for the land-limiting case, or $W_{e w}$, for the water-limiting case, and $W_{m}$ (named range of profitable deficits) the net income associated with the level of deficit is at least as great as it is at full irrigation.

English [13] derived general expressions to estimate the above-mentioned optimal application levels. Assuming that the production function has a quadratic polynomial form (see eq. 1) and the cost function has a linear form (see eq. 3), the author proposed the following explicit expressions (eq. 4 to eq. 10) for $W_{m}$, $W_{l}, W_{w}, W_{e l}$ and $W_{e w}$.

$$
\begin{aligned}
& W_{v}=-\frac{D_{1}}{2 c_{1}} \\
& W_{1}=\frac{b_{+}-P b}{2 P_{c} c_{1}} \\
& W_{v}=\left(\frac{P_{s} \cdot a_{-}-a_{2}}{P_{v} \cdot c_{1}}\right)^{1 / 2} \\
& W_{\omega}=\left(\frac{b_{-}-P b_{1}+Z}{2 P_{c_{1}}}\right)
\end{aligned}
$$

with

$$
\begin{aligned}
& Z_{t}=\left[\left(p_{c_{2}} b_{1}-b_{1}\right)-4 P_{c_{1}} c_{1}+\left(\frac{P b_{1}^{2}}{4 c_{1}}-\frac{b b_{2}}{2 c_{1}}\right)\right]^{1 / 3} \\
& W_{n}=\frac{-Z_{2}+\left[Z_{2}^{2}-4 P c_{1}\left(P a_{1}-a_{2}\right)\right]^{2}}{2 P c_{1}}
\end{aligned}
$$

with

$$
Z_{2}=\frac{P_{c} b_{1}^{2}-4 a_{2} c_{1}+4 P_{c}-a_{1} c_{1}}{2 h_{1}}
$$

Furthermore, equations (12) to (17) can be used when both the production (see eq. 1) and cost (eq. 11) functions have a quadratic form [4].

$$
\begin{aligned}
& c(w)=a_{2}+b_{2} w+c_{2} w^{2} \\
& W_{1}=-\frac{b_{2}-P_{c_{1}}}{2\left(P_{c} c_{1}-c_{2}\right)} \\
& W_{*}=\left(\frac{P_{c_{1}} a_{1}-a_{2}}{P_{c_{1}}-c_{1}}\right)^{1 / 2} \\
& W_{w^{\prime}}=\left(\frac{b_{1}-P_{b_{1}}+Z_{4}}{2\left(P_{1}-c_{2}\right)}\right)
\end{aligned}
$$

with

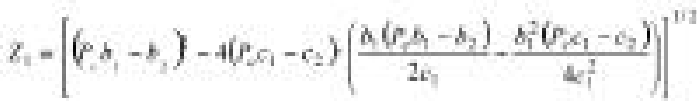

$$
\begin{aligned}
& w_{s=}=\frac{-z_{2}+\left[z_{2}^{2}-4\left(p_{c} a_{1}-a_{2}\right)\left(p_{c_{1}}-c_{1}\right)\right]^{2}}{2\left(P_{c} c_{1}-c_{2}\right)} \\
& Z_{2}=\frac{4\left(\rho_{c} a_{1}-b_{2}\right)_{1}^{2}+b_{1}^{2}\left(P_{c_{1}}-c_{2}\right)}{2 b_{1} c_{1}}
\end{aligned}
$$


The range of profitable deficits (e.g. the range between $W_{m}$, the yield maximizing level, and $W_{e l}$ or $W_{e w}$, the levels of $D I$ where net income will at least equal that at full irrigation) is a qualitative indication of potential risk. The narrower the range of profitable deficits, the higher the risk of error and reductions in income. In the scientific works on DI [among others: $12,13,23,30,39,41,42,44]$ the authors analysed the potential benefits of $D I$ and the range of profitable deficits in different contexts: wheat in North-Western USA, cotton in California, maize in Zimbabwe, winter broccoli, carrot, rape and cabbage in Botswana, barley and sorghum in Iran, almond orchards in South-Eastern Spain. The main results (see Table 1) showed optimal net return with a deficit of $15-59 \%$.

\begin{tabular}{|c|c|c|c|c|c|}
\hline Author & Year & Region & Strategy & Crop & Main effects \\
\hline$[13]$ & 1996 & $\begin{array}{l}\text { NW USA, } \\
\text { California, } \\
\text { Zimbabwe }\end{array}$ & DI & $\begin{array}{l}\text { wheat, } \\
\text { cotton, } \\
\text { maize }\end{array}$ & $\begin{array}{l}\text { optimal net return with } \\
15-59 \% \text { deficit }\end{array}$ \\
\hline [27] & 2000 & Botswana & DI & $\begin{array}{l}\text { broccoli, } \\
\text { carrot, } \\
\text { rape, } \\
\text { cabbage }\end{array}$ & $\begin{array}{l}\text { optimal net return with } \\
20 \% \text { deficit }\end{array}$ \\
\hline$[16]$ & $2003 b$ & Spain & \multirow[t]{2}{*}{ CDI } & garlic & $\begin{array}{c}\text { negative effects in the } \\
\text { bulbification and ripening } \\
\text { stages }\end{array}$ \\
\hline [17] & $2003 a$ & Spain & & beet & $\begin{array}{c}\text { no effects on total } \\
\text { production and industrial } \\
\text { quality index }\end{array}$ \\
\hline [60]. & 2003 & Japan & RDI & potato & $\begin{array}{l}\text { decrease in tuber quantity, } \\
\text { some positive effects on } \\
\text { tuber quality }\end{array}$ \\
\hline$[32]$ & 2004 & Turkey & PRD & $\begin{array}{c}\text { greenhous } \\
\text { e tomato }\end{array}$ & $\begin{array}{c}10-27 \% \text { additional } \\
\text { marketable yield over DI }\end{array}$ \\
\hline$[52]$ & 2004 & Iran & DI & $\begin{array}{l}\text { barley, } \\
\text { sorghum, } \\
\text { maize }\end{array}$ & $\begin{array}{l}\text { optimal net return with } \\
0.6 \text { irrigation efficiency }\end{array}$ \\
\hline [9] & 2005 & $\begin{array}{l}\text { New } \\
\text { Zealand }\end{array}$ & PRD & pepper & $\begin{array}{l}\text { no effect on total dry } \\
\text { mass, significant water } \\
\text { savings }\end{array}$ \\
\hline [20] & 2005 & Spain & RDI & peach & $\begin{array}{l}\text { no effects on fruit } \\
\text { production }\end{array}$ \\
\hline$[58]$ & 2005 & Morocco & PRD+RDI & bean & $\begin{array}{c}\text { decrease in leaf water } \\
\text { potential, shoot and pod } \\
\text { biomass }\end{array}$ \\
\hline$[50]$ & 2006 & Spain & DI & almond & $\begin{array}{c}45 \% \text { of water saved using } \\
\text { RDI with a maximum } \\
\text { production reduction of } \\
17 \%\end{array}$ \\
\hline$[35]$ & 2006 & Denmark & PRD+RDI & potato & $\begin{array}{c}\text { increase in biomass } \\
\text { allocation to root; } \\
\text { decrease in leaf area; } 37 \% \\
\text { water saved }\end{array}$ \\
\hline [56] & 2006 & Thailand & PRD+RDI & mango & $\begin{array}{c}\text { decrease in yield, increase } \\
\text { in fruit size and edible } \\
\text { fraction }\end{array}$ \\
\hline [59] & 2006 & $\begin{array}{c}\text { Uzbekista } \\
\mathrm{n}\end{array}$ & DI & $\begin{array}{l}\text { bean, } \\
\text { green } \\
\text { gram }\end{array}$ & $\begin{array}{c}\text { Water use efficiency } \\
\text { (WUE) increase for green } \\
\text { gram and constant for } \\
\text { bean }\end{array}$ \\
\hline [61] & 2006 & China & RDI & $\begin{array}{l}\text { spring } \\
\text { wheat }\end{array}$ & $\begin{array}{l}\text { increase in yield, biomass, } \\
\text { harvest index and WUE }\end{array}$ \\
\hline [2] & 2007 & Ethiopia & RDI & onion & 6-13\% increase in WUE \\
\hline$[53]$ & 2007 & Denmark & PRD & potato & $\begin{array}{l}30 \% \text { of water saved } \\
\text { maintaining tuber yield, } \\
61 \% \text { increase in WUE }\end{array}$ \\
\hline
\end{tabular}

TABLE 1 - Review of the main Deficit Irrigation strategies in the literature.

\subsection{Regulated deficit irrigation (RDI) and Partial root drying (PRD)}

Regulated Deficit Irrigation $(R D I)$ uses water stress to control vegetative and reproductive growth and it generally imposes water deficits during crop growing phases that are not yield reducing [2, 7, 17, 18, 27]. Precision irrigation strategies, e.g. microirrigation, are paramount for a successful application of $R D I$, as well as timing control and soil water level monitoring. This practice has been adopted successfully for tree crops and mainly for grape [19, 33], peach [7], pear [36] and almond [42] production. Among herbaceous crops, RDI has been applied to cotton [47], garlic [16] sugar beet $[15,35]$ and tomatoes [21]. The reviewed literature (see Table 1) evidenced some relevant factors (both positive and negative) affecting the choice of RDI: it admits furrow irrigation; it controls vegetative growth; fruit size and quality can be achieved; positive effects mainly on grape and wine quality were achieved; it causes potential yield losses; it permits water savings; soil water monitoring is recommended.

In Partial Root Drying ( $P R D)$, a percentage of crop evapotranspiration is applied to alternate plant sides, allowing part of the root system to be in contact with wet soil. In the literature (see Table 1) PRD allows an increase in water use efficiency and a decrease in vegetative vigour without significant reductions in crop yield [9, 10, 29, 30, 34]. The beneficial effects of $P R D$ are hypothesised to be due to a reduction in stomatal conductance and growth by chemical signals, possibly abscissic acid $(A B A)$ synthesized by roots and transported to the leaves in the transpiration stream [31].

The main factors that may affect the choice of $P R D$ are the following: drip irrigation is preferred; alternate row furrow irrigation is possible; no effects on fruit size; vegetative growth can be controlled; positive effects on crop quality; significant water savings; significant cost increase due to doubling laterals in cases where it is not necessary for technical reasons; soil water monitoring is recommended.

\section{Application of an integrated agro-economic ap- proach to DI on lettuce crops in Sicily (Italy)}

\subsection{Methodology}

In the experiment, the effect of four different irrigation levels on the marketable yield and economic return of summer-growth lettuce was evaluated [5, 6]. The field trial was carried out in a randomized design experiment using Lactuca sativa L. (Batavia rossa variety Emini) during two consecutive summer crop production cycles (2005 and 2006). The experimental site is located in Biancavilla, a small village in Eastern Sicily (latitude $34^{\circ} 93^{\prime} \mathrm{N}$, longitude $15^{\circ} 80^{\prime} \mathrm{W}$ and altitude $500 \mathrm{~m}$ above sea level). The lettuce crop was planted at a spacing of $0.25 \mathrm{~m} \times 0.25 \mathrm{~m}$ in an area of about $400 \mathrm{~m}^{2}$; each experiment consisted of four irrigation levels $(125 \%, 100 \%, 75 \%$ and $50 \%$ of actual evapotranspiration, $E T_{a}$ ) with four replications. The crop was irrigated by a surface drip irrigation system with polyethylene pipes $16 \mathrm{~mm}$ in diameter with in- 
line labyrinth drippers (discharge rate of 2 or $41 \mathrm{~h}^{-1}$ at a pressure of $101.2 \mathrm{kPa}$ ). At the beginning of each experiment, system emission uniformity $(E U)$ was determined according to [26], showing values higher than $90 \%$. At the end of the crop growth cycle marketable plants from each treatment plot and replication were weighed and the production loss percentages were evaluated.

Actual evapotranspiration $\left(E T_{a}, \mathrm{~mm} / \mathrm{d}\right)$ was estimated by combining pan evaporation measures (eq. 18) and the Penman-Monteith approach (eq. 19).

$$
\begin{gathered}
E T_{0-P A N}=E_{P A N} \times K_{P} \\
E T_{E-M M}=\frac{0.40 \mathrm{OSA}\left(R_{n}-G\right)+\gamma \frac{900}{T+273} H_{2}\left(\epsilon_{,}-\epsilon_{0}\right)}{\Delta+\gamma\left(1+0.34 u_{2}\right)}
\end{gathered}
$$

The coefficient $\mathrm{K}_{\mathrm{p}}$ was calculated with an equation from Allen et al., (1998) [1].

Following the Bouchet approach [3, 37], on days when the crop is well watered the evapotranspiration rates (potential, crop and actual) are almost equal. When the soil dries off, the plants begin to show some stress and $E T_{a}$ drops below $E T_{O-P M}$ by an amount equal to $E T_{O-P A N}-E T_{O-P M}$.

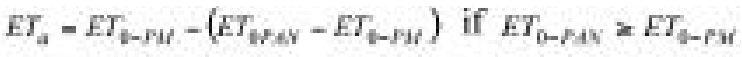

$$
\begin{aligned}
& E T_{a}=E T_{0-r S A} \quad \text { if } E T_{0-P A V}\left\langle E T_{0-P M}\right.
\end{aligned}
$$

The use of the Priestley and Taylor (1972) equation, instead of eq. 19, represents a valid alternative to determine reliable values of the reference evapotranspiration rate [37].

During the monitoring periods soil water samples were collected near the emitter at $0.20,0.40$ and 0.60 $\mathrm{m}$ from the soil surface and gravimetric water analyses were carried out in order to reveal any reduction in soil water content. A spatial description of plant growth was determined by in situ measurements of leaf area index (LAI) using a LICOR ® LAI-2000 portable canopy digital analyzer.

Economic factors concerning gross return (eq. 2) and total costs (eq. 3) were assessed to test the viability of deficit irrigation criteria. Net return was calculated by subtracting total cost from gross revenue. The five levels of optimal applied water described in Section $2.1\left(W_{m}, W_{l}, W_{w}, W_{e l} W_{e w}\right)$ were evaluated (see eq. 4 to eq. 10 for linear cost function and eq. 12 to eq. 17 for quadratic cost function).

\subsection{Results and discussion}

The total irrigation water applied to the field was: $76,113,146,175 \mathrm{~mm}$ (in 2005) and 68, 96, 120, 150 $\mathrm{mm}$ (in 2006) for the 50\%, 75\%, $100 \%$ and $125 \%$ treatments respectively.

Lettuce crop water needs were underestimated using the $E T_{a}$-based approach. In fact, the maximum yield values were for the $125 \% E T$ treatment (corresponding to almost $100 \% E T_{0-P M}$ ). The ratio between the to- tal water received by the crop (IW $125 \%)$ and $E T_{O-P M}$ was almost equal to 1 (as specified in FAO publications). Leaf area index ( $L A I)$ values and soil water contents at selected field locations confirmed some water stress during the middle-end crop growth phases [6].

The average lettuce weight MW (equal to about $0.55 \mathrm{~kg}$ in 2005 and $0.53 \mathrm{~kg}$ in 2006) was influenced by the different rates of applied irrigation water (Table 2). The maximum marketable yields were about $55 \mathrm{t} \mathrm{ha}^{-1}$ in 2005 and $51 \mathrm{t} \mathrm{ha}^{-1}$ in 2006; these values, corresponding to about $180 \mathrm{~mm}$, were recorded in the $125 \%$ treatment plots $\left(100 \% E T_{O-P M}\right)$. Compared to the maximum, the marketable yield decreased by about 6, 12 and $24 \%$ in 2005 and 7, 14 and $30 \%$ in 2006, for the $100 \%, 75 \%$ and $50 \%$ treatments respectively. Mean plant weight decreased by about 5 , 8 and $18 \%$ in 2005, and 7, 14 and $32 \%$ in 2006. Nonmarketable yield increased with an increase in water deficit levels, but the differences between the treatments were not significant.

The regression coefficient values $\left(\mathrm{R}^{2}\right)$ show strong polynomial relationships between marketable yield (TMY, $\mathrm{t} \mathrm{ha} \mathrm{h}^{-1}$ ) and total water received (TW, mm, which includes rainfall) for both 2005 (eq. 22) and 2006 (eq. 23):

$\begin{array}{ll}r M Y=-0.000547 W^{2}+0.26537 \%+25.369 & \mathrm{R}^{2}=0.996(22) \\ r M Y=-0.00157 W^{2}+0.61367 W=8.6849 & \mathrm{R}^{2}=0.996(22)\end{array}$

Following the curves of eqs. (22) and (23), maximum lettuce yield would have been obtained up to approximately $250 \mathrm{~mm}$ and $200 \mathrm{~mm}\left(W_{m}\right)$ during 2005 and 2006 respectively, with corresponding production values of about 57.9 and $54.0 \mathrm{t} \mathrm{ha}^{-1}$. These yield values would have been obtained by increasing irrigation rates by about $40 \%$ in 2005 and $12 \%$ in 2006 with respect to $100 \% E T_{0-P M}$ replenishment. The corresponding increases in crop yield would have been less than $5 \%$.

The best sustained cost $\left(\mathrm{C}\right.$, Euro ha $\left.{ }^{-1}\right)$ curve form resulted in quadratic and linear curves in 2005 and 2006 respectively:

$$
\begin{array}{ll}
C=0.0121 T W^{2}-2.5453 T W+14083 & \mathrm{R}^{2}=0.999(24) \\
C=1.2189 T W+13960 & \mathrm{R}^{2}=0.998(25)
\end{array}
$$

Table 3 lists the optimal levels of applied water as proposed by English (1990) and English and Raja (1996). In the land-limiting case, the estimated optimal economic levels were quite similar to optimal agronomic levels.

In the water deficit case (if land is abundant), the optimal irrigation strategy was that of under-irrigation by $49 \% E T_{O-P M}$ and $90 \% E T_{0-P M}$, thus obtaining water savings of about $51 \%$ in 2005 and $10 \%$ in 2006 . Deficit irrigation ranges, at least as profitable as full irrigation, were $17-49 \% E T_{0-P M}$ and $71-90 \% E T_{0-P M}$ in 2005 and 2006 respectively; within the described 


\begin{tabular}{|c|c|c|c|c|c|c|c|}
\hline \multirow[b]{2}{*}{ Yar } & \multirow[b]{2}{*}{$\begin{array}{l}\text { Tral:- } \\
\text { rat }\end{array}$} & \multicolumn{2}{|c|}{ Darcess 3} & \multicolumn{2}{|c|}{ N-TMYCAI } & \multicolumn{2}{|c|}{ MW is } \\
\hline & & Mlan & 0 & Mas & e & Shas & o \\
\hline \multirow[t]{4}{*}{106} & $115 \%$ & $50 \mathrm{u}(\mathrm{a})$ & 48 & $44(a)$ & 23 & $547(a)$ & \$0. \\
\hline & $100 \mathrm{n}$ & $\$ 0.1 / 2,01$ & 99 & $49(2)$ & 31 & , $\operatorname{cisca0}$ & 902 \\
\hline & 795 & $402 \mathrm{ibh}$ & 66 & 85(2) & 46 & $3 a+(a, b)$ & ras \\
\hline & $\operatorname{ses}$ & acies & 36 & $1030)$ & 55 & 4608 & 351 \\
\hline \multirow[t]{4}{*}{$2 \mathrm{tet}$} & 1250 & $512(a)$ & 33 & 6710 & 26 & $526(0)$ & 335 \\
\hline & $100 \%$ & dx.la.b & 13 & $66(2)$ & 59 & $-457(2,6)$ & 255 \\
\hline & $79 \%$ & $4 \leq \mid \mathrm{b}, \mathrm{e})$ & 4.4 & $21(3)$ & 38 & $453(6)$ & 46 \\
\hline & SWA & $3 s,+i c\rangle$ & 6.1 & $6 X(z)$ & 59 & $198(s)$ & 820 \\
\hline
\end{tabular}

(P-0.0S): the comparison is hetween lises, $\mathrm{g}=$ standard deviation

TABLE 2 - Statistics of yield parameters for different treatments.

\begin{tabular}{|c|c|c|c|c|c|}
\hline \multirow{3}{*}{$\underset{(m \rightarrow m)}{\mathbb{N}}$} & \multicolumn{2}{|c|}{806} & \multicolumn{3}{|c|}{296} \\
\hline & \multicolumn{2}{|c|}{ Netecunmic retums } & \multirow{2}{*}{$\underset{(\mathrm{W})}{\mathrm{W}}$} & \multicolumn{2}{|c|}{ Net councmix returs } \\
\hline & $\begin{array}{l}\text { boted } \\
\text { th the }\end{array}$ & $\begin{array}{l}3 \text { WWikT } \\
\left(\mathrm{mm}^{-1}\right)\end{array}$ & & 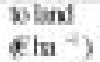 & 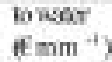 \\
\hline 26 & 13010 & 53.10 & 399 & 1050 & 5267 \\
\hline 24 & 13000 & 54.55 & 198 & $10+30$ & 5290 \\
\hline 86 & 730 & 702 & 158 & 900 & $9 \times 0$ \\
\hline 24) & 13000 & $\$ \$ 00$ & 97 & totso & 5.12 \\
\hline 30 & 170 & 53.60 & 125 & 6060 & 5267 \\
\hline
\end{tabular}

TABLE 3 - Optimal levels of irrigation water and net economic returns.

ranges the grower must define the most appropriate irrigation strategy for optimal water use. The differences between 2005 and 2006 were mainly related to the lower production yields in 2006 due to the sub-optimal climatic conditions (lower air temperature). Obviously, the economic results obtained from the study for the optimal water irrigation levels are related to the market trend in the study area.

\section{Conclusion}

Deficit irrigation is an optimization strategy whereby net returns are maximized by reducing the amount of irrigation water and crops are deliberately allowed to sustain some degree of water deficit and yield reduction. This technique is not usually adopted as a practical alternative to full irrigation by either academics or practitioners due to several obstacles. In particular, it involves the use of precision irrigation; the required knowledge spans over a wide range of disciplines; the strategy involves risks associated with the uncertainty of the required knowledge; it is necessary to persuade farmers and irrigation practitioners not only of the economic value of $D I$ but also of its practicability.

Furthermore, there is a certain amount of confusion regarding the $D I$ concept. A review of about 100 papers dealing with $D I$ recently published in major international journals has shown that only a few papers use the concept of DI in its complete sense (e.g. analysing both the agronomic and economic aspects of $D I$ ). A number of papers only deal with the physiological and agronomical aspects of DI (crop response to different irrigation regimes) without any economic evaluation. Other publications concern Regulated Deficit Irrigation (RDI, or Controlled Deficit Irrigation, $C D I$ ), a strategy based only on a reduction of irrigation during certain plant cycle phases, and Partial Root Drying (PRD), a technique in which a percentage of crop ET is applied to alternating plant sides.

The review of the experimental research shows quite positive effects from $D I$ applications. The positive effects are mostly evidenced when the economics of $D I$ is included in the research approach. The applications present a wide survey of the agronomic effects of $D I$. Generally, total fresh mass and total production are reduced under $D I$, whereas the effects on dry matter and product quality are positive, mainly in crops for which excessive soil water availability significantly influences the size, colour or composition of fruit (grape, tomato, mango, etc.). The economic convenience of $D I$ therefore also depends on the type of crop.

The description of recent trials conducted by the authors in Sicily (Italy), is an example of experimental research integrating the agronomic, engineering and economic aspects of $D I$ at a farm level.

\section{References}

[1] Allen R.G., Pereira L.S., Raes D. and Smith M., Crop evapotranspiration: guidelines for computing crop water requirements. FAO Irrigation and Drainage Paper 56, Rome.

[2] BeKele S., Tilahun K., Regulated deficit irrigation scheduling of onion in a semiarid region in Ethiopia. Agricultural Water Management (2007), published on line 20 February.

[3] BoucheT R.J., Evapotranspiration réel et potentielle, signification climatique. General Assembly (1963), Berkley. Int. Assoc. Sci. Hydrol. 62, 134-142.

[4] CAPRA A., SCICOlONE B., Progettazione e gestione degli impianti di irrigazione. Criteri di impiego e valorizzazione delle acque per uso irriguo. Bologna, Italy: Edagricole, Edizioni agricole de Il sole 24 Ore Editoria specializzata (2007); 297.

[5] Capra A., Consoli S., Russo A., Scicolone B., Effetti agronomici ed economici di regimi irrigui deficitari su ortive: applicazione ad un caso studio in Sicilia. Ia sez. AIIA, Milano 2007.

[6] Capra A., Consoli S., Russo A., Scicolone B., An integrated agro-economic approach to deficit irrigation on lettuce crop in Sicily (Italy). Journal of Irrigation and Drainage Engineering (2008), 134(4), 437-445.

[7] Chalmers D.J., Mitchell P.D., van Heek L., Control of peach tree growth and productivity by regulated water supply, tree density, and summer pruning. J. of American Society of Horticultural Science (1981), 106, 307-312.

[8] Dorji K., Behboudian M.H., Zegbe-DomingueZ J.A., Water relations, growth, yield and fruit quality of hot pepper under deficit irrigation and partial rootzone drying. Scientia Horticulturae (2005), 104, 137-149. 
[9] DrY P.R., LoveYs B.R., DüRING H., BotTing D.G., Effects of partial rootzone drying on grapevine vigour, yield composition of fruit and use of water. In: Stokley, C.S.; Sas, A.N.; Johnstone, R.S.; Lee, T.H., (Eds). Proc. $9^{\text {th }}$ Austr. Wine Ind. Techn. Conf.; Adelaide, Australia: Winetitles, Adelaide (1996), 128-131.

[10] Dry P.R., Loveys B.R., Stoll M., Stewart D., MCCARThY M.G., Partial rootzone drying - an update. Australian Grapegrower and Winemaker (2000), 438a, 35-39.

[11] English M.J., Nuss G.S., Designing for deficit irrigation. J. Irrigation and Drainage Engineering, ASCE, (1982), 108(2), 91-106.

[12] English M.J., Raja S.N., Perspective on deficit irrigation. Agricultural Water Management (1996), 32, 1-14.

[13] EnGLish M.J., Deficit irrigation: an analytical framework. J. of Irrigation and Drainage Engineering, ASCE (1990), 116 (3), 399-412.

[14] English M.J., Salomon K.H., Hoffman G.J., A paradigm shift in irrigation management. J. Irrigation and Drainage Engineering (2002), 128(5), 267-277.

[15] Fabeiro Cortés C., Martín de Santa Olalla F., LóPez URReA R., Production of garlic (Allium sativum L.) under controlled deficit irrigation conditions in a semi-arid climate. Agricultural Water Management (2003), 59, 155-167.

[16] Fabeiro Cortés C., Martín de Santa Olalla F., LÓPEZ R., DOMínguEZ A., Production and quality of the sugar beet (Beta vulgaris L.) cultivated under controlled deficit irrigation conditions in a semi-arid climate. Agricultural Water Management (2003), 62, 215-227.

[17] Girona J., Gelly M., Mata M., Arbones A., Rufat J., Marsal J., Peach tree response to single and combined deficit irrigation regimes in deep soils. Agricultural Water Management (2005), 72, 97-108.

[18] Girona J., Mata M., Arbonés A., Alegre S., Rufat J., Marsal J., Peach tree response to single and combined regulated deficit irrigation regimes under shallow soils. J. American Society Horticultural Science (2003), 128, 432-440.

[19] Girona J., Mata M., del Campo J., Arbonés A., BARTRA E., MARSAL J., The use of midday leaf water potential for scheduling deficit irrigation in vineyards. Irrigation Science (2006), 24, 115-127.

[20] Hargreaves G.H., Samani Z.A., Economic considerations of deficit irrigation. J. Irrigation and Drainage Division, ASCE (1984), 110(4), 343-358.

[21] Hsiao T.C., Growth and productivity of crops in relation to water status. Acta Horticulturae (1993), 335, 137-148.

[22] Hsiao T.C., Steduto P., Fereres E., A systematic and quantitative approach to improve water use efficiency in agriculture. Irrigation Science (2007), 25, 209-231.

[23] Imtiyaz M., Mgadla N.P., Manase S.K., Chendo K., Мотнов E.O., Yield and economic return of vegetable crops under variable irrigation. Irrigation Science (2000), 19, 87-93.

[24] Jalota S.K., Sood A., Chahal G.B.S., Choudhury B.U., Crop water productivity of cotton (Gossypium hirsutum L.)-wheat (Triticum aestivum L.) system as influenced by deficit irrigation, soil texture and precipitation. Agricultural Water Management (2006), 84, 137-146.

[25] JAMES L.D., LEE R.R., Economics of water resources planning. New York, USA, McGraw-Hill (1971), 325.

[26] Karmeli J., Keller D., Trickle irrigation design. Rain bird Mfg corporation (1975), Glendora.
[27] Kirda C., Cetin M., Dasgan Y., Topcu S., Kaman H., Ekici B., Derici M.R., OzGuven A.I., Yield response of greenhouse grown tomato to partial root drying and conventional deficit irrigation. Agricultural Water Management (2004), 69, 191-201.

[28] LECLER N.L., Integrated methods and models for deficit irrigation planning. In Pert, R.M.; Curry, R.B. (Eds), Agricultural systems modelling and simulation, Marcel Dekker Inc. (1998).

[29] Liu F., Shahnazari A., Andersen M., Jacobsen S., JENSEN C., Effects of deficit irrigation (DI) and partial root drying (PRD) on gas exchange, biomass partitioning and water use efficiency in potato. Scientia Horticulturae (2006), 109, 113-117.

[30] Loveys B.R., Grant M.J.R., Dry P.R., McCarthy M.G., Progress in the development of partial rootzone drying. Australian Grapegrower and Winemaker (1997), 414a, 18-20.

[31] Loveys B.R., Stoll M., Dry P.R., McCarthy M.G., Partial rootzone drying simulates stress responses in grapevine to improve water use efficiency while maintaining crop yield and quality. The Australian Grapegrower and Winemaker (1998), 414a, 108-113.

[32] ManNOCCHI F., Mecarelli P., Optimization analysis of deficit irrigation systems. J. of Irrigation and Drainage Engineering, ASCE (1984), 120(3), 484503.

[33] Matthews M.A., Anderson M.M., Schultz H.R., Phenological and growth responses to early and late season water deficits in Cabernet franc. Vitis (1987), 26, 147-160.

[34] MCCARTHY M.G., The effect of transient water deficit on berry development of $c v$. Shiraz, (Vitis vinifera L.). Aust. J. GrapeWine Res. (1997), 3, 102-108.

[35] Miller D.E., Hang A.N., Deficit, high-frequency irrigation of sugar beets with the line source technique. Soil Science Society American J. (1980), 44, 1295-1298.

[36] Mitchell P.D., van Den Ende B., Jerie P.H., Chalmers D.J., Responses of "Bartlett" pear to withholding irrigation, regulated deficit irrigation and tree spacing. J. of the American Society of Horticultural Science (1989), 114, 15-19.

[37] Parlange M.B., Katul G.G., An advection-Aridity evaporation model. Wat. Resour. Res. (1992), 28 (1), 127-132.

[38] PereIRA L.S., OweIs T., ZAIRI A., Irrigation management under water scarcity. Agricultural Water Management (2002), 57, 175-206.

[39] Postel S., Entering an era of water scarcity: the challenges ahead. Ecol. Appl. (2000), 10, 941-948.

[40] Rao N.H., Sarma P.B.S., Chander S., A simple dated water-production function for use irrigated agriculture. Agricultural Water Management (1988), 13, 25-32.

[41] Rao N.H, Sarma P.B.S., Chander S., Irrigation scheduling under a limited water supply. Agricultural Water Management (1988), 15, 165-175.

[42] Romero P., Garcia J., Botia P., Cost-benefit analysis of a regulated deficit-irrigated almond orchard under subsurface drip irrigation conditions in South-eastern Spain. Irrigation Science (2006), 24, 175-184

[43] Sepaskhah A.R., Akbari D., Deficit irrigation under variable seasonal rainfall. Biosystems Engineering (2005), 92(1), 97-106.

[44] SePaskhah A.R., GHahraman B., The effects of irrigation efficiency and uniformity coefficient on relative yield and profit for deficit irrigation. Biosystems Engineering (2004), 87(4), 495-507. 
[45] Shahnazari A., Liu F., Andersen M.N., Jacobsen S.E., JENSEN C.R., Effects of partial root-zone drying on yield, tuber size and water use efficiency in potato under field conditions. Field Crops Research (2007), 100, 117-124.

[46] Shangao S., Mao X., Application of a simulation based optimization model for winter wheat irrigation scheduling in North China. Agricultural Water Management (2006), 85, 314-322.

[47] SNYDER R.L., When water is limited how many acres do you plant? California Agricultural (1992), 47, 7-9.

[48] Spreer W., Nagle M., Neidhart S., Carle R., OngPRASET S., MULLER J., Effect of regulated deficit irrigation and partial rootzone drying on the quality of mango fruits. Agricultural Water management (2006), published on line 28 November.

[49] TOPAK R., SÜERI S., ÇALI_IR S.C., Investigation of the energy efficiency for raising crops under sprinkler irrigation in a semi-arid area. Applied Engineering in Agriculture (2005), 21 (5), 761-768.

[50] Wakrim R., Wahbi S., Tahi H., Aganchich B., SerRAJ R., Comparative effects of partial root drying $(P R D)$ and regulated deficit irrigation (RDI) on water relations and water use efficiency in common bean (Phaseolus vulgaris L.). Agriculture Ecosystem \& Environmental (2005), 106, 275-287.

[51] Webber H.A., Madramooto C.A., Bourgault M., Horst M.G., Stulina G., Smith D.L., Water use efficiency of common bean and green gram grown using alternate furrow and deficit irrigation. Agricultural Water Management (2006) published on line 11 July 2006.

[52] YuAn BZ, NishiYAma S., KANG Y., Effects of different irrigation regimes on the growth and yield of drip-irrigated potato. Agricultural Water Management (2003), 63, 153-167.

[53] Zhang B., Li F.M., Huang G., Cheng Z.Y., Zhang Y., Yield performance of spring wheat improved by regulated deficit irrigation in an arid area. Agricultural Water Management (2006), 79, 28-42.

\section{SUMMARY}

Deficit irrigation $(D I)$ is an optimization strategy whereby net returns are maximized by reducing the amount of irrigation water; crops are deliberated allowed to sustain some degree of water deficit and yield reduction. Although the $D I$ strategy dates back to the 1970 s, this technique is not usually adopted as a practical alternative to full irrigation by either academics or practitioners. Furthermore, there is a certain amount of confusion regarding its concept. In fact, a review of recent literature dealing with $D I$ has shown that only a few papers use the concept of $D I$ in its complete sense (e.g. both the agronomic and economic aspects). A number of papers only deal with the physiological and agronomical aspects of $D I$ or concern techniques such as Regulated Deficit Irrigation $(R D I)$ and Partial Root Drying $(P R D)$. The paper includes two main parts: i) a review of the principal water management strategies under deficit conditions (e.g. conventional $D I, R D I$ and $P R D)$; and ii) a description of a recent experimental research conducted by the authors in Sicily (Italy) that integrates agronomic, engineering and economic aspects of $D I$ at farm level. Most of the literature reviewed here showed, in general, quite positive effects from $D I$ application, mostly evidenced when the economics of $D I$ is included in the research approach. With regard to the agronomic effects, total fresh mass and total production is generally reduced under $D I$, whereas the effects on dry matter and product quality are positive, mainly in crops for which excessive soil water availability can cause significant reductions in fruit size, colour or composition (grapes, tomatoes, mangos, etc.). The experimental trial on a lettuce crop in Sicily, during 2005 and 2006, shows that the highest mean marketable yield of lettuce $\left(55.3 \mathrm{t} \mathrm{ha}^{-1}\right.$ in 2005 and $51.9 \mathrm{t} \mathrm{ha}^{-1}$ in 2006) was recorded in plots which received $100 \%$ of $E T_{O-P M}$ (reference evapotranspiration by the PenmanMonteith method) applied water. In the land-limiting case, the estimated optimal economic levels were quite similar to the optimal agronomic levels. In the waterlimiting case $D I$ ranges, at least as profitable as full irrigation, were of $17-49 \% E T_{O-P M}$ and of $71-90 \% E T_{0-P M}$ in 2005 and 2006 respectively.

\section{Key words:}

Deficit irrigation, Economics of deficit irrigation, Evapotranspiration, Yield production features.

\section{Notation}

$a_{1}, b_{1}, c_{1}=$ coefficients of the crop production curve

$a_{2}, b_{2}, c_{2}=$ coefficients of the cost function curve

$C=$ sustained cost

$c(w)=$ cost function

$C D I=$ controlled deficit irrigation

$\Delta=$ slope of the saturation vapour pressure curve

$D I=$ deficit irrigation

$E_{P A N}=$ pan evaporation

$e_{-}-e_{a}=$ vapour pressure deficit

$E T_{a}=$ actual evapotranspiration

$E T_{0-P A N}=$ reference evapotranspiration by pan evaporation

$E T_{O-P M}=$ reference evapotranspiration by Penman-Monteith (PM) approach

$E U=$ emission uniformity

$G=$ soil heat flux density

$\gamma=$ psychrometric constant

$I W=$ irrigation water

$\underline{K}=$ crop coefficient

$\underline{K}_{\mathrm{c}}=$ pan evaporation coefficient

$L A I=$ leaf area index

$M W=$ mean weight

$N-T M Y=$ no-marketable yield

$P=$ probability level

$P_{c}=$ prize per unit of weight

$P R D=$ partial root drying

$R^{2}=$ regression coefficient

$R D I=$ regulated deficit irrigation

$R_{n}=$ net radiation

$R(w)=$ revenue per hectare

$\sigma=$ standard deviation

$T=$ daily mean air temperature

$T M Y=$ total marketable yield

$T W=$ Total water received

$u_{2}=$ wind speed

$w=$ depth of applied water

$W=$ mean applied water

$W_{e l}=$ level of applied water at which net income equals that at full irrigation when land is limiting

$W_{e w}=$ level of applied water at which net income equals that at full irrigation when water is limiting

$W_{l}=$ level at which net income per unit of land is maximised

$W_{m}=$ level at which crop yield per unit of land is maximised

$W_{w}^{m}=$ level at which net income per unit of water is maximised

$W U E=$ water use efficiency

$y(w)=$ crop production function 